\title{
African Migrants and Remittances: Impact on Growth and Development of their Home Countries
}

\author{
Siméon Maxime Bikoue \\ Advanced School of Economics and Commerce \\ University of Douala, P.O. Box 1931, Douala, Cameroon \\ Tel: 237-699-921-061 E-mail: maximebikoue@yahoo.fr
}

Received: July 29, 2020 Accepted: August 25, 2020 Published: September 14, 2020

doi:10.5296/ber.v10i3.17686 URL: https://doi.org/10.5296/ber.v10i3.17686

\begin{abstract}
This paper aims to study the impact of remittances from African migrants on their home countries' growth and development. These funds constitute a steadily increasing financing means in all these countries, even though development aid is still the preferred financing method. To highlight the role of these funds, we relied on a number of experiences as far as their targets and uses are concerned. Globally speaking, stylized facts based on case studies show that remittances have a positive impact on migrants' home countries' economies. In particular, they reduce household poverty and thereby increase their well-being. In addition, they stimulate local economic activity and growth. Given the role and stability of these funds, cost reduction is essential to encourage migrants to send more money through official transfer channels. It is also necessary to increase the managerial efficiency of these funds by orienting them towards implementing profitable projects, rather than devoting them entirely to household consumption. Lastly, it is necessary to encourage the capture of related financial flows by the traditional banking system and microfinance institutions.
\end{abstract}

Keywords: African migrants, Remittances, Economic growth, Development

\section{Introduction}

Each year, Africa loses many of its most skilled workers to the benefit of the Northern countries. According to Kouarné (2000), this phenomenon, described as a brain drain, is longstanding. It dates back to independence. It has been intensified over the past decade with an average loss of 20,000 professionals per year (See table A. 1 in the appendix). It is a great concern in home countries, especially as host regions now seem to make every effort to encourage skilled immigration.

The loss of the most skilled labour force from African countries could nonetheless be offset 
by remittances sent by these professionals to household or community members in their native countries. Indeed, remittances represent the second largest source of external financing for developing countries, after foreign direct investment and public development aids (Ratha, 2003). In a context of aid declining trends and the absence or failure of production and credit markets for local production structures, funds from migration can help finance local activities and contribute to develop countries providing migrants.

The effects of international migration in terms of economic development in migrants' countries of origin remain ambiguous. Migration is recognized as a selective process. The most educated and dynamic are those who decide to migrate. It is questionable whether remittances from migrants can actually make up for the resulting deficit. They could lead to dependency, enabling households to specialize in migration instead of using the money to invest in local productive projects.

This investigation examines the impact of remittances from African migrants on their countries of origin. The objective is threefold: We will first make an inventory of the importance of emigration in Africa. Secondly, the scale and determinants of remittances from African migrants will be highlighted and thirdly, the impact of these funds on the growth and development of their home countries will be examined.

\section{Migration: Some Key Elements}

According to the United Nations' data, the number of international migrants has generally increased by about 14\% between 1990 and 2000, from 154 to 175 million. As concerns Africa, the number of migrants virtually remained stable over the same period: 16.2 million in 1990 and 16.3 million in 2000 (Cameroon is the home country of 1,434 among the 95,153 migrants with tertiary education residing in the United States in 1990 [Carrigton and Detragiache (1998) quoted by Kouamé (2000)]).

Lucas (2005) believes that one of the defining features of international migration in Africa lies in its extreme instability over time. As a matter of fact, several African countries alternate between immigration and emigration regions. Table A.2 in the appendix shows the five-year net migration rates for the 1975-2000 period. Although sub-Saharan Africa as a whole has experienced net migration during this period, there are some particularities depending on countries. In Cameroon for instance, the net migration rate is positive between 1975 and 1980, and between 1980 and 1985 (1.45 and 0.46 respectively). However, it is negative between 1985 and 1990, and 1990 and 1995 (-1.05 and -0.08 respectively), and zero between 1995 and 2000. The relatively favourable economic and socio-political situation of the country between 1975 and 1985 seems to be a limiting factor for the departure of its nationals. However, it favoured the arrival of foreigners, especially from neighbouring countries. Between 1985 and 1995, it was a period of economic crisis and political jousting (early 1990s). This phase was somehow featured by the incentive of Cameroonians to leave the country, hoping to find better life elsewhere. Finally, between 1995 and 2000, with the slight economic recovery and a decline in social tensions, not to mention the policies applied by most host countries to fight against immigration, many people found it better to stay in their country. 
According to Docquier and Marfouk (2004), migration rates have slightly changed in most African countries, while they have considerably increased in Latin America.

This study is most focussed on African migrants to the OECD countries who represent about 25 percent of the total migrant population according to the World Bank. In 2000 and in line with Table A.3, there were 2.8 million migrants from sub-Saharan African countries to OECD countries about $0.45 \%$ of the overall original population). This proportion is low compared to other regions of the world as Asia which has the highest stock of migrants.

The African countries with the highest absolute numbers of migrants in the OECD countries in 2000 were South Africa, Nigeria, Kenya and Angola, with more than 190,000 migrants. Cameroon is far behind with 57,050 migrants. Moreover, apart from Lesotho, the number of migrants from all the other countries listed in Table A.3 has increased between 1990 and 2000. Migrants mostly settle in former metropolises. Thus, those from French-speaking African countries settle in France, while nationals from English-speaking African countries settle in England or the USA. Cultural reasons are often mentioned. The language for instance allows migrants to be quickly integrated in their host countries.

Population migrations in developing countries mainly concern the most skilled workers. According to Page and Plaza (2005), Latin America and Africa are the two regions of the developing world where the most highly skilled professionals reside in developed countries. The number and proportion of the most qualified Latin American and African populations living in the OECD countries are provided in Table A.4. As concerns Africa, it appears that South Africa and Nigeria have the highest numbers of skilled migrants in both absolute and relative values. Despite the low absolute value of the most skilled migrants in Africa, their proportion compared to the total number of migrants to the OECD countries is higher than in Latin America. According to Adepoju (2002), the most skilled migrants - doctors, teachers, engineers, researchers - have higher wages and better living conditions elsewhere (World Bank, 2006).

Globally speaking, most of the sub-Saharan African countries lose a significant share of their skilled labour every year. This situation is further accentuated by the host countries' current immigration policy which favours the integration of the most skilled migrants. In fact, in response to the growing shortage of skilled workers, many host countries have attempted to shift the focus of their immigration policies with the aim of promoting the recruitment of highly skilled workers (Faini, 2007). This new turning point in immigration policies has become a source of considerable concerns in traditional migration countries which fear losing their full productive potential.

However, some authors believe that the loss of highly skilled labour from migrant-sending countries is offset by remittances from the migrants to their families.

\section{Remittances and Economic Situation}

In recent years, remittances have been more closely examined by academics, policymakers, migrant associations and some financial institutions. For instance, the latest Global Economic Prospects report published by the World Bank at the end of 2006 was entirely devoted to the 


\section{Macrothink}

Business and Economic Research ISSN 2162-4860 2020, Vol. 10, No. 3

economic implications of remittances and migration (See table A.5 in the appendix). In this section, we will stress on the extent of remittances from African migrants, analyse their determinants and study their economic impact on migrants' home countries.

\subsection{The Importance of Remittances in Africa}

The renewed interest in remittances can be explained by the increasing volume of official financial transfers to low-income countries, and by their potential influence on recipient countries' development. According to the World Bank estimates, developing countries have received official remittances amounting to $\$ 251$ billion in 2007. This figure represents an increase of about $11 \%$ compared to the amount received in 2006, and $29 \%$ compared to that of 2005 (Note 1).

It goes without saying that the share of the various regions in this total amount varies. While the Diasporas of Latin America and the Caribbean, as well as those of South Asian sent \$ 61 billion and $\$ 44$ billion respectively to their home regions, the Diasporas of sub-Saharan Africa have barely officially transferred $\$ 12$ billion (Ratha, 2008).

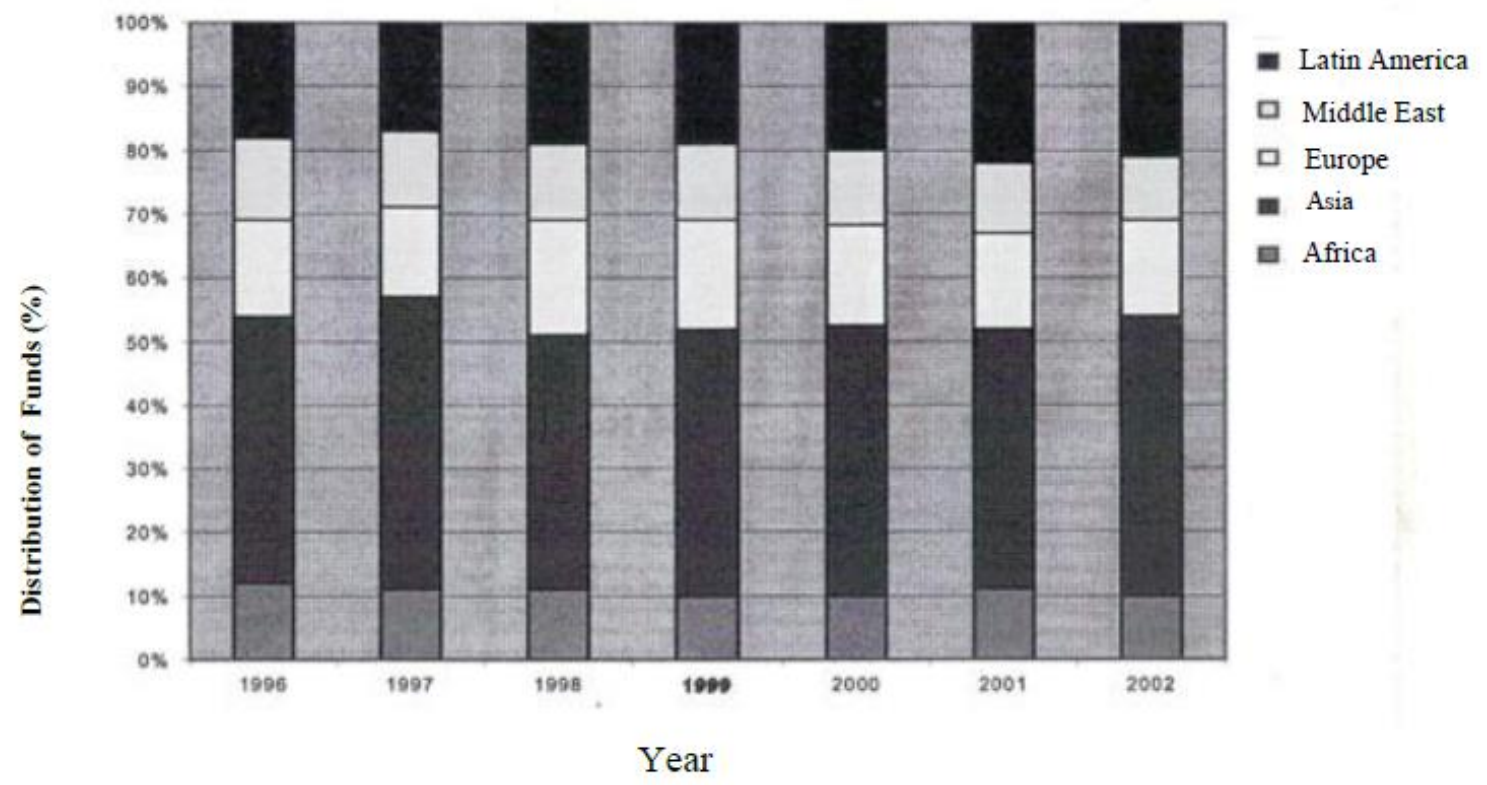

Figure 1. Transfer of funds to developing countries by region 1990, 2002

Source: IMF, Balance of Payments' Statistical Yearbook

Figure 1 shows a better view of the distribution of migrant transfers in different regions of the world. We note that these funds are not evenly distributed. In this regard, Asia is the most solicited destination. From 1996 to 2002, 40 to 46 percent of annual transfer flows are in Asia. Latin America and the Caribbean come next with 17 to 22\%, Eastern Europe with 15 to $18 \%$. Lastly, Africa comes with 10 to $12 \%$ of transfer flows. This result is not surprising since Asia is the most populous region of the world with the largest diaspora on the planet.

Looking at the absolute value of remittances by country in sub-Saharan Africa, Ratha et al. 
(2008) estimate that the top ten countries which benefited from these transfers in 2007 were Nigeria ( $\$ 3.3$ billion), Kenya ( $\$ 1.3$ billion), Sudan ( $\$ 1.2$ billion), Senegal ( $\$ 0.9$ billion), Uganda ( $\$ 0.9$ billion), South Africa ( $\$ 0.7$ billion), Lesotho (\$ 0.4 billion), Mauritius (\$ 0.2 billion), Togo ( $\$ 0.2$ billion) and Mali ( $\$ 0.2$ billion) (Note 2$)$.

Table 1 shows that migrant remittances to sub-Saharan Africa have steadily increased since 1990. However, in contrast to all developing countries, their annual amounts in this period remain lower than other types of international financing, especially Official Development Assistance and Foreign Direct Investment. In some countries - Botswana, Ivory Coast, Lesotho, Swaziland, Togo and Mauritius - remittances, however, were higher than official development assistance. In Lesotho, Swaziland, Mauritius and Togo, these funds were also higher than foreign direct investment (Ratha et al., 2008).

Table 1. Financial flows to sub-Saharan Africa (in billion of dollars)

\begin{tabular}{|l|l|l|l|l|l|l|}
\hline Year Types of flows (1) & 1990 & 1995 & 2000 & 2005 & 2006 & Variation 2000-06 (\%) \\
\hline ODA & 17 & 17.8 & 12.2 & 30,8 & 38,2 & 213.11 \\
\hline FDI & 1.1 & 4.5 & 6.8 & 19,3 & 17,1 & 151.47 \\
\hline PI & 0.4 & 3 & 4.2 & 7.4 & 15.1 & 259.5 \\
\hline R & 1.8 & 3.2 & 4.3 & 8.8 & 10.3 & 139.5 \\
\hline
\end{tabular}

(1) Four types of flows were identified; ODA = Official Development Assistance; FDI = Foreign Direct Investment; PI = Portfolio Investment; R = Remittances. Source: From the Table provided by Ratha et al. (2008); Global Development Finance database, Tuesday, 2008.

These figures do not include non-registered remittances. Indeed, money can be sent through informal channels (friends or families), Non-Governmental Organizations (NGOs), religious missions and the like. In countries with dysfunctions in the formal financial system like most poor countries, informal channels are often the only way to transfer money. As a result, informal remittances may exceed those officially registered (De Bruyn and Kuddus, 2005; Maimbo and Ratha, 2005).

In developing countries in general and sub-Saharan Africa in particular, remittances from migrants are therefore an external source of steadily rising capital. If foreign direct investment and capital flows have drastically dropped in recent years due to recession in high-income countries, remittances by migrants have continued to increase. At the beginning of the 1980s, the importance of these transfers was already recognized to offset the loss of human capital in developing countries due to migration (Faini, 2007). The question then is whether this compensation is "pure". In other words, do skilled migrants send more money than low-skilled ones?

\subsection{Do Skilled Migrants Send More Funds?}

According to the World Bank (2006), "the brain drain negative effects are to some extent offset by remittances from migrant workers". Some investigations establish a positive relationship between migrants' qualification level and the amount of funds sent. In other 
words, the volume of remittances from migrant workers tends to increase with their skills level [Johnson and Whitelaw (1974), Rempel and Lobdell (1978) quoted by Faini (2007)]. However, not all empirical research confirms this relationship. The unfinished literature leaves many unanswered questions. First, the empirical results are mixed. Rodriguez and Horton (1994) quoted by Faini (2007) show that in Philippines, migrants' qualification level has no impact on the amount of funds transferred. Secondly, according to Faini (2007), it is possible that skilled workers are from wealthy families with high educational level, and that the incentives to send money are therefore lower. Finally, they may spend more time abroad, either because they are more inclined to gather their families in the host country, or because they have less difficulty in doing so. Indeed, a characteristic result of literature is that transfers tend to decline with the duration of migration (Lucas and Stark, 1985). Therefore, even a positive educational impact on the amount of remittances cannot be evidence that brain drain is associated with huge transfers. The direct qualifications impact can actually be positive, but the overall impact, which takes into account the fact that skilled migrants tend to stay abroad for a long time may be negative as well.

While focusing on the change in the composition of migration made up of more skilled migrants with higher wages, Faini (2006) finds that high salaries have two contradictory effects on funds transfer to the home country:

(a) a "salary" effect where higher remunerations are associated with huge transfers to those who remain in the country;

b) a "clustering" effect where higher wages allow migrants to gather their immediate family members, which has a negative impact on the amount of transfers. The overall impact of a more skilled migration on transfers is therefore an empirical issue. Generally speaking, the results of the above author suggest that a more skilled migration is correlated with smaller transfers.

\subsection{Determinants of Remittances}

The level of remittance flows made by a migrant depends both on his/her potential (that is, on his/her income and savings) and his/her motivation to repatriate his/her savings in his/her home country. Of course, the willingness to make these transfers also depends on the time to spend during migration (how long do migrants intend to stay abroad - temporarily or permanently?), on migrants' familial status (single, married, with or without children) and network effects (do they migrate alone, accompanied by their families, are they still connected to those left behind?).

One of the methods of studying the determinants of transfer flows is to analyse migrants' key motives when sending money. Research on the issue distinguishes between pure altruism, mere self-interest and unspoken arrangements with the family left behind in their country of origin. As Stark (1991) points out, there is no general theory as far as remittances are concerned. Investigations on this phenomenon provide valuable descriptive data as well as empirical research results, but it is partially explained, and these studies have a number of limitations. 


\section{Pure Altruism}

One of the most intuitive motivations for sending money back to the home country is what investigations on the issue call "altruism"; in other words, the migrants' concern for the well-being of their families in their native countries. According to the altruistic model, the migrant is satisfied with the idea of the well-being of his/her parents.

The utility function of the altruistic migrant can be represented according to Faini (2007) by:

$$
\mathrm{U}=\mathrm{U}\left(\mathrm{C}_{\mathrm{M}}, \mathrm{C}_{\mathrm{F}}\right)
$$

Where $C_{M}$ and $C_{F}$ are the respective consumption levels of the migrant and his/her family members who remain in the country. There are two budgetary constraints: that of the emigrant

$$
\mathrm{C}_{\mathrm{M}}{ }^{=} \mathrm{Y}_{\mathrm{M}}-\mathrm{R}_{\mathrm{M}}
$$

Where $Y_{M}$ represents the migrant's earnings and $R_{M}$ the transfers; and that of the family members in the home country:

$$
C F=Y_{F}+R_{F}
$$

where $Y_{F}$ represents the family income and $R_{F}$ the amount of transfers received. We suppose that

$\mathrm{R}_{\mathrm{F}}=\mathrm{R}_{\mathrm{M}}$, in other words, the amounts sent and received are equal.

By substituting budgetary constraints (equations 2 and 3) in the objective function and by maximizing with respect to $\mathrm{R}$, we obtain the condition of first order:

$$
\mathrm{U}_{\mathrm{m}}\left(\mathrm{C}_{\mathrm{m}}, \mathrm{C}_{\mathrm{F}}\right)=\mathrm{Uf}\left(\mathrm{C}_{\mathrm{m}}, \mathrm{C}_{\mathrm{F}}\right)
$$

where $U_{i}$ is the marginal utility relative to $C_{i}(\mathrm{i}=\mathrm{M}, \mathrm{F})$. Therefore, at the optimum, the marginal utility of $\mathrm{C}_{\mathrm{M}}$ must be equal to that of $\mathrm{C}_{\mathrm{F}}$. This framework can be used to assess the impact of $Y_{F}$ variation on transfers. Assuming that transfers remain constant at the outset, a decline in $Y_{F}$ leads to a decrease in $\mathrm{C}_{\mathrm{F}}$ and an increase in the marginal utility of family consumption $\left(\mathrm{U}_{\mathrm{F}}\right)$. To restore balance, transfers should therefore increase.

This model is based on several assumptions. First, the amount of transfers is supposed to increase along with the migrant's income. Second, this amount should decrease as family income increases. Third, the amount should decrease over time as family ties become more distorted. It should be the same when the migrant permanently settles in the host country, and the members of his/her family come to join him/her. Empirical evidence for Botswana corroborates the first argument. An increase of $1 \%$ in the migrant's salary implies, all other things being equal, an increase in the amount of transfers ranging from $0.25 \%$ to $0.73 \%$ for low and high wages respectively. However, after finding that the correlation between the level of transfers and the income level in the home country is insignificant, it can be concluded that altruism alone is not enough to explain the motivations for making transfers, at least as concerns Botswana (Lucas and Stark, 1985). 


\section{Simple Personal Interest}

Remittances to family members in the native country may have another reason, that of the migrant's personal interest. First, a migrant can send money to loved ones while thinking about the inheritance, as long as bequests are subordinate to heirs' behaviour. Second, owning property in one's home country can encourage the migrant to send money to parents living there so as to make sure that the caregivers do the right thing. Empirical data from Kenya and Botswana show that the beneficiary parents feel better as the share of salary transferred by the migrant is huge (Hoddinott, 1994; Lucas and Stark, 1985). However, it is unclear whether the reason is the inheritance prospect or the concern to see parents take care of the property belonging to the migrant. Third, according to Stark (1991), the intention to go back to one's country may also push the migrant to transfer funds in order to invest in real estate, financial assets and public goods (which will enhance his/her prestige and political influence within the local community), and/or in social capital (relationships with family and friends for instance). This is particularly the case for most workers from the Cameroonian western region living abroad, who increase their remittances as their final return back to their home country is approaching.

\section{Tacit family arrangements: co-insurance and loans}

Arrangements made by households, especially within the extended family, may be considered more complex in reality, and certainly more balanced than in the case of the two extremes, pure altruism and simple self-interest. For instance, Lucas and Stark (1985) explain the motivations for transferring funds, using a model called "temperate altruism". In this model, the decision to make transfers falls within a family context, these transfers constituting an endogenous aspect of the migratory process. If we look at the household as a whole, remittances should be a mechanism for redistributing earnings. Two main sources of potential gain are taken into account: the dilution of risks and investment in young family members' education. In this context, the arrangement within a family is considered an "implicit co-insurance agreement", or an "implicit family loan agreement". This tacit contract between the migrant and his/her family is protected from the break-up by familial own assets being credit and loyalty, but also, by the purely migrant's personal motives as the idea to inherit, invest in his/her home region in property that the family will take care of, and the intention to go back to his/her country with dignity.

In the implicit co-insurance model, it is assumed that initially, the migrant plays the role of an insured, and the family in the home country that of the insurer. The family finances the initial cost of the migration project which, in most cases, represents a significant amount. In a second phase of the migration process, the migrant himself/herself can also play the role of the insurer for his/her family members in the native country. It is assumed that this is possible if the migrant already has a secure job, earns a high enough wage and intends to increase his/her income. By receiving the money transferred, the family has the opportunity to improve their consumption, embark on investment projects with much greater risks and thus make themselves much more useful. Evidence from Botswana shows that families with the most livestock receive much more cash transfers during drought periods (Lucas and Stark, 
1985).

\subsection{The Impact of Remittances on Home Countries' Economies}

The impact of migration transfers on the development of migrants' native countries is controversial. If there is any consensus, it is on that these transfers represent, on the macro-economic scale, a non-negligible source of currencies. They could also have a significant impact on the well-being of individuals and households concerned, but also, on the economic development of their home countries as a whole.

\section{Improving families' living conditions}

Transfers can cover, to a greater or lesser extent, families' consumption needs whose cash income is often low and unstable in their country. By increasing incomes and diversifying their sources, migrants' money helps to improve families' daily lives and deal with crisis situations as drought or famine. Savina Ammassari (2005) conducted a study of 340 Ghanaians and 300 Ivorians who came back from abroad and settled in their respective cities. In line with this investigation, migrants reported that the sums transferred were most frequently used to meet family needs. In particular, $84 \%$ of Ivorians and $75 \%$ of Ghanaians primarily used them to take care of their families. In fact, several studies in Africa corroborate this result and highlight the critical importance of these resources for migrant households, not only in times of crisis, but also, in ordinary moments.

A Ghanaian migrant to London explained that the 100 pounds he sent each month to his parents were used to take care of them, pay for electricity and water bills, public transport and other daily expenses.

There is some consensus that remittances help reduce poverty. For instance, Adams and Page (2003) estimate on a sample of about one hundred countries, that a $10 \%$ increase in remittances per capita is followed by a $3.5 \%$ drop in poverty rate. Although these results are questionable, several microeconomic studies using household surveys point in the same direction. In Egypt, the number of poor rural households declined by $10 \%$ when remittances were included in their incomes, which account for almost $15 \%$ of their total income (Adams, 1991). Remittances could help reduce poverty by 11 percentage points in Lesotho (from 63\% to 52\%), 11 points in Uganda, 6 points in Bangladesh and 5 points in Ghana (Adams, 2005). Lachaud (1999) shows that remittances in Burkina Faso contribute in reducing the incidence of rural poverty by 7.2 percentage points, and urban poverty by 3.2 .

Transfers can also be a form of insurance against uncertainties. The New Economics of Labour Migration (NELM) takes into account the specificities of the departure zones, essentially rural, as well as the constraints and risks weighing on these populations. Given the virtual absence of insurance or credit markets in most sub-Saharan African rural areas, migration funds provide a form of protection, insurance against uncertainties and precariousness of populations residing in these areas (Daum, 1998). This money can also make it easier for family members and relatives to access essential basic services as health and education. Serving as a safety net and offsetting (in part) the lack of a social protection and insurance system, these funds contribute in reducing poverty and strengthening people's 
capacities to participate in the developmental process.

There is also a close relationship between money transfers and income distribution. In empirical assessments, most investigations in line with the impact of remittances on income distribution use the Gini index. Studies show that remittances have accentuated the inequalities measured by this index. One of the main reasons for this fact is that wealthy families are more able to pay international migration's costs than others. For instance, data collected in Egypt show that despite poverty reduction (because a great number of poor households actually benefit from money transferred), remittances have increased income inequality (Adams, 1991).

\section{Investment Achievements}

Remittances can be earmarked for investments, specifically for projects in home countries which may be strictly private (building or acquisition of housing, creation of small businesses, trade, etc.) In this case, migratory incomes stimulate local economic activity and thus growth, and somehow replace loans and other financing modes very often inaccessible to the poor populations and less adapted to their needs. By loosening the particularly strong financial constraint in rural areas, these incomes enable to invest in new activities or techniques favourable to an increase in agricultural productivity. In Botswana, Malawi or Zambia for instance, there is an undeniable link between savings transfer and improvements in rural areas, particularly in irrigation (Daum, 1998).

Migrants from the Kayes region (Mali) are the main actors in local development through village associations. They are being attributed $60 \%$ of infrastructures in the region. The Malian community is perfectly structured on the organizing model of villages. The village chief has his representative among the migrants, and each association created in France is copied on the hierarchical structure and the social order of the village (Penent, 2003).

The Economic Initiatives and Migration Programme (EIMP), implemented since 2001 by the NGO pS-Eau, aims at supporting the economic projects of migrants from sub-Saharan Africa and North Africa: resettlement projects in their home countries, remote investment and creation projects in France. This programme runs a network of a dozen support operators (the Business Creation Support Group). The "Remote Investment" scheme allows migrants to use their savings as a guarantee for loans to start an economic activity in their country of origin. For the migrant, it is about securing economic investments in Senegal or Mali (these investments are both an alternative to financial transfers for consumption, and a complement to the social investments of associations). For the Senegalese or Malian promoter relating to the migrant, it is a facilitated access to the financing of an economic activity. For the banking organization, it is a "new product" and a specific service to offer to migrants. This type of investment meets the expectations of migrants living generally with their families in France, and benefiting from a stable family and professional status. It concerns migrants with available savings who wish to invest in an economic activity rather than making recurrent transfers for family consumption.

It should be noted that if, in the right circumstances, a significant percentage of remittances 
can be allocated to productive companies, one may still wonder why such savings' orientation only occurs in some communities. According to Massey et al. (1993), it is clear that factors behind peoples' migration are also very often those limiting the productive potential of remittances. Thus, the lack of public services or the poor state of infrastructures seriously limit the "productive" potential of remittances. Many migration areas in poor countries are villages far from markets which lack basic infrastructure. Migration is likely to have a greater impact on development where minimum conditions are met thanks to the intervention of local institutions, and when the migrant is not expected to play alone the roles of worker, saver, investor and producer.

Remittances can also have negative effects depending on how they are used. Among these effects, one often quotes the predominance in migrants' families, of the consumption logic on that of accumulation. The satisfaction of new consumption habits usually implies an increase in imported goods (Peoples in developing countries in general and Africa in particular are extremely influenced by Western lifestyles and habits).

Similarly, the review of empirical studies of developing countries by Gubert $(2000,2001)$ shows that if there is no doubt on the importance of transfers in households' income, their impact is quite different on agricultural production and productivity. In some cases, remittances compensate the loss of labour force resulting from migration by allowing the hiring of agricultural workers and equipment acquisition. In others, transfers are bad for agriculture as they provide families with the opportunity to maintain the same income level while reducing their labour supply. Such a phenomenon, which can be described as annuitant, is followed by a contraction in agricultural production. In the case of the Kayes region in Mali, data shows that despite a better endowment of agricultural equipment, families participating in international migration significantly reach lower production levels than those obtained by families without migrants, and this without the result being attributable to the lack of manpower (Gubert, 2000).

\section{Conclusion}

African migrants' behaviours on remittances to their country of origin reflect their commitment in improving the economic and social situation of those left behind. These transfers constitute a very important capital source for African countries. They have been steadily increasing since 1990. However, in contrast to all developing countries, their annual amounts are still lower than those of other types of international funding, especially the Official Development Assistance.

Remittances to home countries are often underestimated, as money can be sent through informal channels. In countries with dysfunctions in the formal financial system like most poor countries, informal channels are often the only way to transfer money. As a result, informal remittances may exceed the volume of officially registered ones. The reduction of transfer costs is likely to increase the amount of money transferred by migrants, and also allow the use of formal channels.

The question we wanted to answer in this study was whether funds transferred have a positive 
impact on the development and economic growth of migrants' home countries.

Empirical studies suggest that the economic impact of remittances remains ambiguous. In addition to their direct impact on the economies of migrants' home countries (reducing poverty, reducing foreign exchange shortages, productive investment, etc.), transfers also have positive indirect effects. They attenuate capital and risk constraints, facilitate the release of other investment resources and have a multiplier effect on consumer spending.

Nevertheless, remittances are not a panacea and cannot be a substitute the sound economic policies in developing countries. On the other hand, if the economic context pushes for migration, the impact of transfers on the development of the migrant's home regions is lessened. The best way to maximize the positive effects of remittances on growth in African countries will be to apply models of sound economic management and developmental strategies involving all economic actors. These controversies suggest that much empirical research still needs to be conducted to highlight the actual effects of remittances in each particular economic context.

Generally speaking, the main issues currently being addressed are the different measures to be taken to improve the developmental impact of remittances. Four measures are taken into account:

Firstly, migrant associations must be involved in strategic initiatives in the field of remittances and work collaboratively with public authorities and NGOs.

Secondly, the capture of related financial flows by the traditional banking system and microfinance institutions should be encouraged.

Thirdly, host countries must provide undocumented migrants with access to official remittance channels.

Fourthly, it is necessary to increase the managerial efficiency of these funds by orienting them towards the realization of profitable projects rather than devoting them entirely to household consumption.

\section{References}

Adams, R. H. (1991). The Effects of International Remittances on Poverty, Inequality and Development in Rural Egypt. Research Report no 96, International Food Policy Research Institute.

Adams, P., \& PAGE, J. (2003). International Migrations, Remittances and Poverty in Developing Countries. Policy Research Working Paper $\mathrm{n}^{\circ} 3179$, World Bank (Poverty Reduction group), Washington, DC.

Adams, R. H. (1991). Remittances, Poverty and Investment in Guatemala. In S. Maurice \& C. Ozden (Eds.), International Migration, Remittances and the Brain Drain. Washington DC, Banque Mondiale.

Adepoju, A. (2002). Fostering free movements of persons in West Africa: Achievements, 
constraints, and prospects for international migration. International Migration, 40(2). https://doi.org/10.1111/1468-2435.00188

Ammassari, S. (2004). From Nation-building to Entrepreneurship: the Impact of Elite Return Migrants in Côte d'Ivoire and Ghana. Population, Space and Place, 10(2).

https://doi.org/10.1002/psp.319

Brown, R. (1997). Estimating Remittance Functions for Pacific Island Migrants. World Development, 25(4), 613-626. https://doi.org/10.1016/S0305-750X(96)00122-2

De Bruyn, T., \& Kuddus, U. (2005). Dynamics of Remittance Utilization in Bangladesh. IOM, Geneva. https://doi.org/10.18356/e227e838-en

Carling, J. (2005). Migration Remittances and Development Corporation. International Peace Research Institute.

Daum, C. (1998). Développement des pays d'origine et flux migratoire : la nécessaire déconnexion. Homme et Migration, № 1214, Juillet-Août 1998.

https://doi.org/10.3406/homig.1998.3194

Djajic, S. (1998). Emigration and Welfare in an Economy with Foreign Capital. Journal of Development Economies, 56, 433-445. https://doi.org/10.1016/S0304-3878(98)00073-X

Docquier, F., \& Marfouk, A. (2004). Measuring the international mobility of skilled workers (1990-2000). Policy Research Working Paper $\mathrm{n}^{\circ}$ 3381, the World Bank, Washington. https://doi.org/10.1596/1813-9450-3381

Docquier, F., \& Rapoport, H. (2003). Remittances and Inequality: A Dynamic Migration Model. IZA Discussion Paper $n^{\circ}$ 808, Institute for the Study of Labor, Bonn.

Faini, R. (2006). Remittances and the brain drain. CEPR Discussion Paper n. 4031, CEPR London. https://doi.org/10.2139/ssrn.918433

Faini, R. (2007). Migrations et transferts de fonds. Impact sur les pays d'origine. Revue d'économie du développement, 2-3(21), 153-182. https://doi.org/10.3917/edd.212.0153

Gubert, F. (2001). L'effet des transferts des émigrés maliens sur leur famille d'origine.

Gubert, F. (2000). Migration et gestion collective des risques. L'exemple de la région de Kayes(Mali), Thèse de doctorat, Clermont-Ferrand, Université D'Auvergne.

Hoddinott, J. (1994). A Model of Migration and Remittances Applied to Western Kenya. Oxford Economic. https://doi.org/10.1093/oxfordjournals.oep.a042141

International Monetary Fund. (2005). World Economic Outlook: Globalization and external Imbalances. chapter 2, Washington, DC.

Kouame, A. (2000a). Exode des compétences et développement des capacités : quelques réflexions à partir du cas camerounais. Conférence Régionale sur l'Exode des Cerveaux et la Construction des Capacités en Afrique, Commission Economique pour $\mathrm{P}$ Afrique, Addis Abeba 22-24 Février 2000. 


\section{Macrothink

Lachaud, J. P. (1999). Envois de fonds, inégalité et pauvreté au Burkina Faso. Revue TiersMonde, 160, 793-827. https://doi.org/10.3406/tiers.1999.5346

Lowell, B. L., \& de la Garza, R. Q. (2000). The Developmental Role of Remittances in US Latino Communities and in Latin American Countries. A Final Project Report, InterAmerican Dialogue.

Lucas, R. E. B. (2005). Migration and Economic Development in Africa: A review of Evidence. Paper prepared for the African Economic Research Consortium Biannual Research Workshop, Nairobi.

Lucas, R. E. B. (1990). Why doesn't capital flow from rich to poor countries?. American Economic Review, 80(2), 92-96.

Maimbo, S. M., \& Ratha, D. (2005). Remittances. Development Impact and Future Prospects, World Bank, Washington, DC. https://doi.org/10.1596/0-8213-5794-8

Massey, D. S. (1993). International Migration and Business Formation in Mexico. Social Science Quarterly, 79(1), 1-20.

Page, J., \& Plaza, S. (2005). International Migration and Economic Development: A Review of Global Evidence. Paper presented at the Plenary Session of African Economic Research Consortium, Nairobi.

Penent, A. (2003). Valorisation économique de l'épargne des migrants: Epargner ici, investir là-bas, un état des lieux, CFSI, Décembre 2003.

Quibria, M. G. (1997). International Migration, Remittances and Income Distribution in Source Country: A Synthesis. Bulletin of Economic Research, 49(1), 29-46.

https://doi.org/10.1111/1467-8586.00025

Rajan, R., \& Subramanian, A. (2005a). Aid And Growth: What Does The Cross- Country Evidence Really Show?. NBER Working Paper 11513, NBER, Cambridge, Mass. https://doi.org/10.3386/w11513

Rajan, R., \& Subramanian, A. (2005b). What Undermines Aid's Impact On Growth?. NBER Working Paper 11657, NBER, Cambridge, Mass. https://doi.org/10.3386/w11657

Rhata, D. (2003). Workers Remittances: An Important and Stable Source of External Development Finance. In Global Development Finance, World Bank.

Ratha, et al. (2008a). Beyond Aid: News Sources and Innovative Mechanisms for financing Development in Sub-Saharan Africa. Policy Research Working Paper $n^{\circ} 4609$, The World Bank, Development Prospects Group Migration and Remittances Team. https://doi.org/10.1596/1813-9450-4609

Rhata, D. (2008b). Revisions to Remittance Trends 2007. In Migration and Development Brief 5, Development Prospects Group, Migration and Remittance Team.

Stark, O. (1991). La migration dans les pays en développement: les risques, les transferts et la 
famille. Finances et Développement, 36(4), 39-41.

Straubhaar, T., \& Vadean, F. P. (2006). Les transferts de fonds internationaux des émigrés et leur impact dans le développement. In Perspectives des migrations internationales, OCDE, pp. 149-174. https://doi.org/10.1787/9789264013919-3-fr

Taylor, J. E. (1999). The New Economies of Labor Migration and the Role of Remittances. International Migration, 37(1), 63-86. https://doi.org/10.1111/1468-2435.00066

Taylor, J. E., \& Wyatt, T. J. (1996). The Shadow Value of Migrant Remittances, Income and Inequality in a Household-farm Economy. Journal of Development Studies, 32(6), 899-912. https://doi.org/10.1080/00220389608422445

United Nations. (2005). The World Economic Survey (2004).

World Bank. (2005). Global Economic Prospect 2005. Economic Implications of Remittances and Migration, World Bank, Washington DC.

\section{Notes}

Note 1. It should be noted, however, that this ranking changes when assessing migrant remittances as a percentage of the GDP. In this case, Losotho comes first with transfers estimated at $25 \%$ of the GDP, followed by Gambia and Cape Verde with $12.5 \%$ and $12 \%$ respectively.

Note 2. Since 1996, pS-Eau has been providing the secretary in France / support and reflection service of the Local Development Migration Program (LDMP), a public support system for reintegration through the creation of economic activities in Senegal, France, Mali and Mauritania. Partnerships established in the North and South and actions carried out in this framework since 1996 have enable to define the objectives and the content of the Economic Initiatives and Migration Program, which opened to creation in France and in both areas.

\section{Appendices}

Table A. 1. International migrants by region of destination in million, 1960 - 2000

\begin{tabular}{|l|l|l|l|l|l|}
\hline Year & 1960 & 1970 & 1980 & 1990 & 2000 \\
\hline Region & 32.1 & 38.3 & 47.7 & 89.7 & 110.3 \\
\hline Developed nations & 29.1 & 35.2 & 44.5 & 59.3 & 80.8 \\
\hline Developed countries without the USSR & 43.8 & 43.2 & 52.1 & 64.3 & 64.6 \\
\hline Developing countries & 9.0 & 9,9 & 14,1 & 16.2 & 16,3 \\
\hline Africa & 29.3 & 28.1 & 32.3 & 41.8 & 43.8 \\
\hline Asia & 6.0 & 5.8 & 6,1 & 7.0 & 5.9 \\
\hline Latin America and the Caribbean & 12.5 & 13.0 & 18.1 & 27.6 & 40.8 \\
\hline North America & 2.1 & 3.0 & 3,8 & 4.8 & 5.8 \\
\hline Oceania & 14.0 & 18,7 & 22.2 & 23.0 & 32.8 \\
\hline Europe & 2.9 & 3.1 & 2.3 & 30.3 & 29.5 \\
\hline Former USSR & 75.9 & 81.5 & 99.8 & 154.0 & 174.9 \\
\hline
\end{tabular}

Source: United Nations Î2Û031 
Table A. 2. Net Migration Rates per thousand population : 1975-2000

\begin{tabular}{|c|c|c|c|c|c|}
\hline & 1975- & $1980-$ & 1985- & $1990-$ & $1995-$ \\
\hline & 1980 & 1985 & 1990 & 1995 & 2000 \\
\hline Eastern Africa & -1.09 & -0.65 & -0.11 & -8.60 & -13.02 \\
\hline Burundi & -2.83 & 4.33 & -0.11 & -8.60 & -13.02 \\
\hline Comoros & 5.68 & -2.14 & -1.83 & 0.00 & 0.00 \\
\hline Djibouti & 56.77 & 5.65 & 38.49 & -10.95 & 6.57 \\
\hline Eritrea & 0.00 & 0.00 & 0.00 & -22.42 & -0.23 \\
\hline Ethiopia & 11.77 & 3.21 & 3.54 & 3.35 & -0.15 \\
\hline Kenya & -0.04 & 0.04 & 0.05 & 1.74 & -0.15 \\
\hline Madagascar & -071 & -0.17 & -0.13 & -0.09 & -0.04 \\
\hline Malawi & -0.35 & -0.31 & 20.95 & -17.13 & -093 \\
\hline Mauritius & -4.41 & -5.45 & -5.77 & -1.28 & -0.35 \\
\hline Mozambique & 1.54 & -5.89 & -19.46 & 9.79 & 1.01 \\
\hline Reunion & -9.54 & 0.72 & -0.62 & 2.68 & 2.45 \\
\hline Rwanda & -2.18 & -3.96 & 0.48 & -57.56 & 61.49 \\
\hline Somalia & 59.79 & -25.37 & -16.06 & -21.86 & 1.71 \\
\hline Uganda & -2.70 & -1.56 & 3.11 & 1.44 & -0.60 \\
\hline United Republic of Tanzania & -025 & 0.36 & 0.57 & 4.16 & -1.25 \\
\hline Zambia & 0.19 & 1.51 & 0.85 & -0.16 & 1.74 \\
\hline Zimbabwe & -3.08 & 3.74 & 2.71 & -3.28 & -0.25 \\
\hline Middle Africa & 0,20 & -0.43 & -0.09 & 3.71 & -3.27 \\
\hline Angola & 0.58 & 6.12 & -341 & 2.83 & -2.07 \\
\hline Cameroon & 1.45 & 0,46 & -1.05 & -0.08 & 0.00 \\
\hline Central African Republic & -0.09 & 3.25 & -2.94 & 2.38 & 0.64 \\
\hline Chad & -5.37 & -3.41 & 1.53 & 0.63 & 2.73 \\
\hline Congo & 0.00 & 0.11 & 0.18 & 1.05 & 2.60 \\
\hline Democratic Republic Congo & 0.77 & -2.31 & 0.43 & 5.90 & $-6,40$ \\
\hline Equatorial Guinea & -26.85 & 48.77 & 0.00 & 0.00 & 0.00 \\
\hline Gabon & 6.17 & 5.31 & 4.53 & 3.88 & 2.43 \\
\hline Soa Tome and Principe & -2.53 & -10.68 & -4.42 & -3.24 & -2.86 \\
\hline Southern Africa & -0.05 & 0.73 & 0.39 & 0.25 & -0.26 \\
\hline Botswana & -2.05 & -1.66 & -1.54 & -1.01 & -0.86 \\
\hline Lesotho & -3.27 & -2.27 & -7.28 & -7.37 & -4.15 \\
\hline Namibia & -9.16 & -5.39 & 11.78 & 0.46 & 2.27 \\
\hline South Africa & 0.54 & 1.16 & 0.25 & 0.81 & -0.16 \\
\hline Swaziland & -2.95 & 0.33 & 5.98 & -8.37 & -1.09 \\
\hline Western Africa & 0.40 & -0.80 & -0.71 & -0.71 & -0.45 \\
\hline Benin & -4.85 & -3.75 & -3.23 & 1.84 & -3.20 \\
\hline Burkina Faco & -6.73 & -5.98 & -3.07 & -2.66 & -2.30 \\
\hline Cape Verde & -17.37 & -11.11 & -10.10 & -4.65 & -2.42 \\
\hline Cote d'Ivoire & 11.07 & 9.11 & 4.35 & 2.98 & 0.80 \\
\hline Gambia & 7.29 & 7.01 & 10.53 & 8.78 & 7.42 \\
\hline Ghana & -10.77 & 3.40 & -0.42 & 0.49 & -1.19 \\
\hline Guinea & 1.55 & -1.52 & 2.45 & 10.41 & -7.18 \\
\hline Guinea-Bissau & 17.45 & -0.04 & 0.35 & 3.63 & -1.68 \\
\hline Liberia & 1.38 & 0.00 & -34.17 & -26.51 & 35.89 \\
\hline Mali & -5.25 & -5.81 & -5.65 & $\begin{array}{c}-5.37 \\
\end{array}$ & -5.10 \\
\hline Mauritania & -1.28 & -1.88 & -3.15 & -1.36 & 0.80 \\
\hline Niger & -0.71 & -0.81 & -0.52 & 0.12 & -0.12 \\
\hline Nigeria & 2.87 & -1.94 & -0.23 & -0.21 & -0.18 \\
\hline Senegal & 0.78 & 0.35 & 0.00 & -1.79 & -1.13 \\
\hline Sierra Leane & 0.00 & 0.00 & 3.29 & -18.68 & -5.19 \\
\hline
\end{tabular}




\begin{tabular}{|l|l|l|l|l|l|}
\hline Togo & -8.36 & 3.64 & 0.06 & -6.67 & 6.06 \\
\hline Sub-Saharan Africa & -1.35 & -2.35 & -0.35 & -1.53 & -0.94 \\
\hline
\end{tabular}

Source: UN population, Division, Dept of Economic and Social Affairs, World population prospects: 2002 Revision.

Table A.3. Migrants from Sud-Saharan Africa to the OECD Countries

Migrant in OECD Stock increase 1990-2000

\begin{tabular}{|c|c|c|c|c|c|}
\hline \multicolumn{6}{|c|}{ Migrant in OECD Stock increase 1990-2000 } \\
\hline & & $\begin{array}{l}\text { Per } 1000 \\
\text { Home Population }\end{array}$ & & $\begin{array}{l}\text { Per } 1000 \\
\text { Home Population }\end{array}$ & $\begin{array}{l}\text { Percent of } \\
1990 \text { stock }\end{array}$ \\
\hline Eastern Africa & $1,060,496$ & 4.20 & 285,351 & 1.28 & 53.4 \\
\hline Burundi & 10,095 & 1.61 & 3,654 & 0.62 & 110.5 \\
\hline Comoros & 17,723 & 25.14 & 6,484 & 10.53 & 182.2 \\
\hline Djibouti & 5,359 & 8.05 & 851 & 1.42 & 108.0 \\
\hline Eritrea & 35,127 & 9.46 & & & \\
\hline Ethiopia & 113,938 & 1.74 & 38,347 & 0.67 & 57.0 \\
\hline Kenya & 197.445 & 6.46 & 47,738 & 1.76 & 38.1 \\
\hline Madagascar & 75,954 & 4.76 & 10,503 & 0.75 & 60.6 \\
\hline Malawi & 15,024 & 1.32 & 4,179 & 0.40 & 49.2 \\
\hline Mauritius & 86,410 & 72.86 & 14,648 & 13.06 & 22.5 \\
\hline Mozambique & 85,337 & 4.78 & 13,862 & 0.88 & 29.8 \\
\hline Reunion & 14,832 & 1.92 & 5,584 & 0.77 & 147.7 \\
\hline Rwanda & 7,602 & 96.23 & 623 & 8.31 & 10.5 \\
\hline Seychelles & 131,342 & 15.06 & 58,285 & 7.34 & 142.9 \\
\hline Somalia & 82,232 & 3.50 & 17,635 & 0.86 & 30.34 \\
\hline Uganda & 70,006 & 2.01 & 13,853 & 0.45 & 28.3 \\
\hline U. Rep. of Zambia & 34,825 & 3.34 & 15,349 & 1.65 & 118.0 \\
\hline Zimbabwe & 77,345 & 6.11 & 33,757 & 2.92 & 131.8 \\
\hline Middle Africa & 469,787 & 5.05 & 110,088 & 1.34 & 54.0 \\
\hline Angola & 195,675 & 15,80 & 31,246 & 2.88 & 34.9 \\
\hline Cameroon & 57,050 & 3.77 & 24,785 & 1.85 & 128.5 \\
\hline Central African & 9,855 & 2.65 & 1,667 & 0.50 & 56.0 \\
\hline Republic & 5,836 & 0.74 & 1,060 & 0.15 & 62.7 \\
\hline Chad & 100,052 & 29.03 & 25,642 & 8.63 & 242.2 \\
\hline Congo & 66,488 & 1.37 & 15,362 & 0.36 & 20.5 \\
\hline Dem. Rep. Congo & 12,149 & 26.64 & 7,964 & 19.66 & 4488.6 \\
\hline Equatorial Guinea & 10,951 & 8.71 & 1,964 & 1.78 & 91.9 \\
\hline Gabon & 11,732 & 78.74 & 396 & 2.99 & 14.6 \\
\hline \multicolumn{6}{|c|}{ Soa Tome and Principe } \\
\hline Southern Africa & 353,733 & 7.05 & 157,848 & 3.41 & 133.7 \\
\hline Botswana & 4,298 & 2.49 & 1,968 & 1.28 & 244.8 \\
\hline Lesotho & 995 & 0.56 & -283 & -0.17 & -32.2 \\
\hline Namibia & 3,390 & 1.79 & 803 & 0.49 & 66.7 \\
\hline South Africa & 342,947 & 7.79 & 154,264 & 3.82 & 134.8 \\
\hline Swaziland & 2,103 & 2.01 & 1,095 & 1.16 & 140.1 \\
\hline Western Africa & 902,564 & 3.99 & 409,687 & 2.06 & 111.5 \\
\hline Benin & 13,669 & 2.20 & 4,069 & 0.75 & 80.8 \\
\hline Burkina Faso & 6,237 & 0.52 & 3,246 & 0.31 & 102.9 \\
\hline Cape Verde & 83,291 & 191.03 & 14,131 & 36.00 & 35.8 \\
\hline Cote d'Ivoire & 58,843 & 3.72 & 22,509 & 1.59 & 133.6 \\
\hline
\end{tabular}




\begin{tabular}{|l|l|l|l|l|l|}
\hline Gambia & 20,923 & 15.95 & 12,070 & 10.74 & 206.8 \\
\hline Ghana & 150,665 & 7.69 & 81,315 & 4.66 & 101.0 \\
\hline Guinea & 19,684 & 2.43 & 7,098 & 1.00 & 102.7 \\
\hline Guinea-Bissau & 29,449 & 21.54 & 7,716 & 6.48 & 258.5 \\
\hline Liberia & 41,756 & 14.19 & 24,818 & 9.77 & 229.4 \\
\hline Mali & 45,034 & 3.78 & 10,891 & 1.04 & 44.6 \\
\hline Mauritania & 14,813 & 5.60 & 6,842 & 2.93 & 141.9 \\
\hline Niger & 4,948 & 0.46 & 535 & 0.06 & 34.0 \\
\hline Nigeria & 247,497 & 131,443 & 2.16 & 1.31 & 133.5 \\
\hline Saint Helena & 2,460 & 492.00 & & & \\
\hline Senegal & 104,715 & 11.15 & 46,189 & 5.52 & 96.6 \\
\hline Sierra Lean@ & 40,556 & 9.19 & 25,043 & 5.91 & 233.6 \\
\hline Togo & 18,024 & 3.95 & 11,773 & 2.94 & 148.7 \\
\hline Sub-Saharan Africa & $2,786,580$ & 4,48 & 962,974 & 1.75 & 78.7 \\
\hline
\end{tabular}

Sources : Dumont and Lemaître 120041; Docquier and Marfonk (2005)

Table A.4. Number of Highly Skilled Expatriates in Latin and Africa

\begin{tabular}{|l|l|l|l|l|l|l|}
\hline \multicolumn{7}{|l|}{ Total Number of Highly Skilled Expatriates in Latin America and Africa } \\
\hline & Latin America & & & Africa & \\
\hline & Total \% of & Number of & & Total & \% of & Number of \\
\hline & Number Highly & highly & & Number & Highly & highly \\
\hline Country & Expatriates Skillet & skilled & Country & of & skillet & skilledd \\
\hline & & immigrants & & Expatriaites & & immigrants \\
\hline Jamaica & 79604624.0 & & South & & 47.9 & \\
\hline Colombia & 68215625.7 & 191051 & Africa & & 55.1 & 164272 \\
\hline Brazil & 35187831.7 & 171221 & Nigeria & 342947 & 37.4 & 136371 \\
\hline Peru & 36150630.2 & 111545 & Kenya & 247497 & 34.0 & 73844 \\
\hline Argentina & 26607037.8 & 109175 & Ghana & 197445 & 36.6 & 51226 \\
\hline Haiti & 46689719.8 & 100574 & Congo & 150665 & 31.2 & 36619 \\
\hline Trinida and & 27693429.5 & 92446 & Ethiopia & 100052 & 43.3 & 35517 \\
\hline Tobago & 20046140.2 & 81696 & Zimbabwe & 113838 & 39.2 & 33490 \\
\hline Venezuela & 30554424.9 & 80585 & Uganda & 77345 & 41.0 & 32235 \\
\hline Guyana & 49026715.4 & 76080 & Tanzania & 82232 & 32.0 & 28702 \\
\hline Ecuador & 20036633.0 & 75501 & Madagascar & 70006 & 28.0 & 24305 \\
\hline Chile & 8395117.8 & 66121 & & 75954 & 23.1 & 24195 \\
\hline El Salvador & 14063132.6 & 65482 & Mauritius & 86410 & 42.3 & 24189 \\
\hline Panama & 22453117.9 & 45846 & Senegal & 104715 & 26.5 & 24132 \\
\hline Nicaragua & 4897728.2 & 40191 & Cameroon & 57050 & 32.5 & 22614 \\
\hline Guatemala & & 40161 & Mozambique & 85337 & & 21609 \\
\hline & & & & 66488 & & \\
\hline
\end{tabular}

Table A.5. Remittance flows to Developing countries (\$Billions)

\begin{tabular}{|l|l|l|l|l|l|l|l|l|l|l|l|}
\hline & 1990 & 1995 & 2000 & 2001 & 2002 & 2003 & 2004 & 2005 & 2006 & 2007 & $2006-07$ \\
\hline World & 69 & 102 & 129 & 143 & 170 & 206 & 234 & 266 & 303 & 337 & $11 \%$ \\
\hline Developing countries & 31 & 57 & 82 & 92 & 115 & 143 & 163 & 194 & 226 & 251 & $11 \%$ \\
\hline Lower middle income & 18 & 36 & 47 & 51 & 71 & 89 & 95 & 110 & 127 & 140 & $10 \%$ \\
\hline Upper middle income & 6 & 36 & 13 & 17 & 30 & 38 & 48 & 60 & 70 & 78 & $11 \%$ \\
\hline Low income & 8 & 9 & 22 & 24 & 15 & 17 & 20 & 24 & 29 & 33 & $15 \%$ \\
\hline
\end{tabular}




\begin{tabular}{|l|l|l|l|l|l|l|l|l|l|l|l|}
\hline $\begin{array}{l}\text { Latin America } \\
\text { and the Caribbean }\end{array}$ & 6 & 13 & 20 & 24 & 28 & 35 & 42 & 48 & 57 & 61 & $6 \%$ \\
\hline South Asia & 6 & 10 & 16 & 16 & 24 & 30 & 29 & 33 & 40 & 44 & $11 \%$ \\
\hline $\begin{array}{l}\text { East Asia } \\
\text { and the Pacific }\end{array}$ & 3 & 10 & 17 & 20 & 29 & 35 & 39 & 47 & 53 & 59 & $11 \%$ \\
\hline $\begin{array}{l}\text { Middle -East } \\
\text { and North Africa }\end{array}$ & 12 & 13 & 14 & 15 & 15 & 20 & 23 & 24 & 27 & 29 & $8 \%$ \\
\hline $\begin{array}{l}\text { Europe and } \\
\text { Central Asia }\end{array}$ & 3 & 8 & 11 & 11 & 14 & 16 & 23 & 32 & 39 & 47 & $22 \%$ \\
\hline Sub- Saharan Africa & 2 & 3 & 5 & 5 & 5 & 6 & 8 & 10 & 11 & 12 & $7 \%$ \\
\hline
\end{tabular}

Source: Word bank staff Estimates on IMF BoP Yearbook 2004/2008 and country desks

\section{Copyright Disclaimer}

Copyright for this article is retained by the author(s), with first publication rights granted to the journal.

This is an open-access article distributed under the terms and conditions of the Creative Commons Attribution license (http://creativecommons.org/licenses/by/4.0/). 